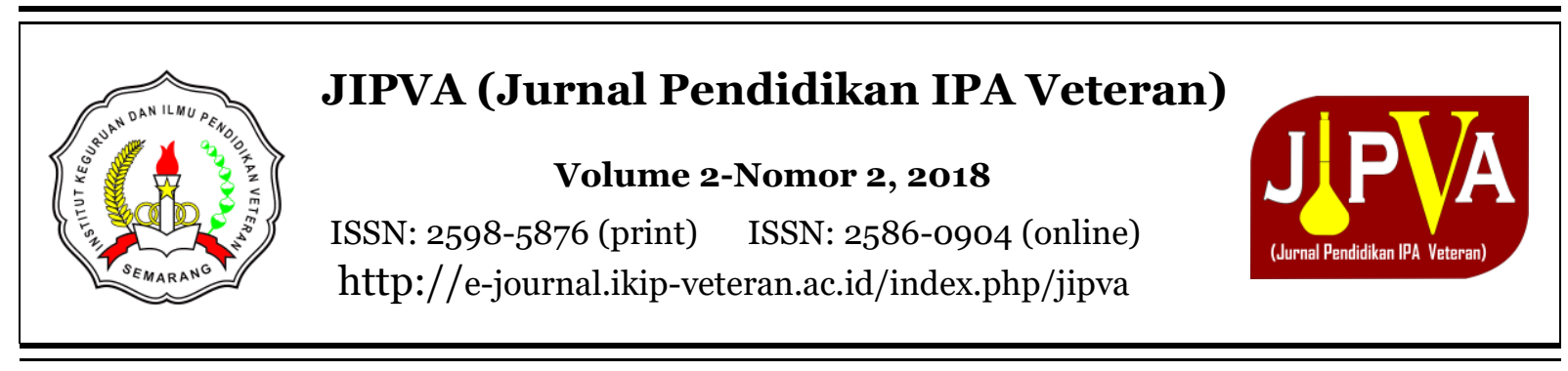

\title{
Analisis Aktivitas Peserta Didik dalam Pembelajaran Berbasis Scientific Approach di Sekolah Dasar sebagai Implementasi 21st Century Skills
}

\author{
Din Azwar Uswatun ${ }^{1}$, Rohmat Widiyanto ${ }^{2}$ \\ ${ }^{1}$ PGSD FKIP Universitas Muhammadiyah Sukabumi, Kota Sukabumi, Indonesia ${ }^{1)}$ \\ ${ }^{2}$ PGMI Universitas Islam Negeri Syarif Hidayatullah, Jakarta, Indonesia ${ }^{2)}$ \\ *Corresponding author email: dinazwar@ummi.ac.id \\ Received: 09 September 2018; Revised: 18 November2018; Accepted: 23 November 2018
}

\begin{abstract}
Abstrak
Penelitian ini bertujuan untuk mendeskripsikan aktivitas peserta didik setelah mengikuti proses pembelajaran dengan scientific approach. Metode penelitian ini dilakukan dengan menggunakan metode penelitian deskriptif analitik dengan pendekatan kualitatif. Objek penelitian ini adalah peserta didik sekolah dasar yang menjadi sasaran implementasi Kurikulum 2013 yang ada di lingkungan Dinas Pendidikan Kota Sukabumi. Teknik pengambilan sampel dengan menggunakan teknik sampling purposive. Waktu penelitian dilakukan pada semester genap tahun ajaran 2017/2018 (Januari $2018 \mathrm{~s} / \mathrm{d}$ Juli 2018). Teknik pengumpulan data yang digunakan antara lain: wawancara dan observasi. Teknik analisis data menggunakan teknik analisis deskriptif. Hasil penelitian menunjukkan bahwa aktivitas belajar peserta didik dalam kegiatan mengamati (observing) mencapai 98,44\%, menanya (questioning) mencapai 87,50\%, mengumpulkan informasi/eksperimen (experimenting) mencapai 59,62\%, mengasosiasikan/mengolah informasi (associating) mencapai 87,50\%, dan mengkomunikasikan (communicating) mencapai $62,50 \%$. Secara rata-rata keseluruhan aktivitas peserta didik dalam mengikuti proses pembelajaran di sekolah dasar dengan scientific approach tercapai 76,60\% dengan kategori Baik. Oleh karena itu, aktivitas peserta didik harus lebih dikembangkan lagi dalam setiap tahapan scientific approach selama proses pembelajaran.
\end{abstract}

Kata Kunci: Aktivitas Belajar, Scientific Approach, Proses Pembelajaran.

\section{Analysis of Student Activities in Learning Based on Scientific Approach in Primary School as Implementation $21^{\text {st }}$ Century Skills}

\begin{abstract}
The objective of this study is to explain the mapping of students activities after following the learning process with the scientific approach. The method of this study was descriptive analytic research methods with a qualitative approach. The object of this study was elementary school students who were the target of the 2013 curriculum implementation in the Sukabumi City Education Office. The sampling technique using purposive sampling technique. The time of the research was conducted in the even semester of 2017/2018 school year (January 2018 until July 2018). The data collection techniques used include: interviews and observations. The data analysis techniques using descriptive analysis techniques The results of this study showed that students' learning activities in observing activities reached $98.44 \%$, questioning reached $87.50 \%$, experimenting reached $59.62 \%$, associating reached $87.50 \%$, and communicating reached $62.50 \%$. On average, the overall students activities in following the learning process in elementary schools with the scientific approach reached $76.60 \%$ with the Good category. Thus students activities must be further developed in each scientific approach during the learning process.
\end{abstract}

Keywords: Students Activities, Scientific Approach, Learning Process. 
How to Cite: Uswatun, D., \& Widiyanto, R. (2018). Pemetaan Learning and Innovation Skills Peserta Didik dalam Pembelajaran Berbasis Scientific Approach. JIPVA (Jurnal Pendidikan IPA Veteran), 2(2), 174-188. doi:10.31331/jipva.v2i2.680

\section{PENDAHULUAN}

Pada Abad 21 ini, Indonesia menghadapi era Masyarakat Ekonomi ASEAN (MEA). Hal ini menuntut perhatian dari semua sektor terlebih sektor pendidikan yang menempati urutan terdepan dalam upaya pembangunan Sumber Daya Manusia (SDM) Indonesia. Pendidikan menjadi semakin penting untuk menjamin peserta didik memiliki keterampilan belajar dan berinovasi, keterampilan menggunakan teknologi dan media informasi, serta dapat bekerja, dan bertahan dengan menggunakan life skills. Oleh karena itu, pemberlakuan MEA menjadi momentum yang baik untuk melakukan perbaikan-perbaikan pada sektor pendidikan Indonesia agar mampu menghasilkan SDM yang memiliki daya saing tinggi. Pendidikan direalisasikan melalui proses pembelajaran (Liliasari, 2012).

Peran guru sebagai pendidik profesional mempunyai tugas sangat penting dalam mencerdaskan kehidupan bangsa. Guru profesional harus mempunyai empat kompetensi guru yang sudah ditetapkan dalam undang-undang yaitu kemampuan dalam menguasai materi pembelajaran secara luas, menguasai cara mendidik dan membelajarkan (pedagogik), kompetensi kepribadian, dan kompetensi soasial. Guru berkewajiban melakukan pengembangan keprofesian secara terus menerus dan proporsional.

Profesionalisme pendidik di era MEA dapat dilihat dari kondisi SDM Indonesia saat ini, permasalahan yang dihadapi dalam bidang pendidikan di Indonesia, hingga bagaimana respon lembaga pendidikan dalam menghadapi gelombang perubahan di Abad ke-21. Oleh karena itu, arah kebijakan pendidikan di Indonesia pada era Masyarakat Ekonomi ASEAN menempatkan peningkatan kualitas SDM, khususnya pengembangan pendidikan sebagai prioritas nasional. Era MEA menuntut sekolah harus memiliki peran strategis sebagai lembaga pendidikan penyedia sumber daya manusia yang unggul. Peran tersebut yaitu melakukan peningkatan kualitas dan sosialisasi kepada peserta didik dan orang tua wali tentang dampak berlakunya MEA agar mereka meningkatkan daya saingnya.

Kenyataannya pencapaian prestasi belajar peserta didik Indonesia di bidang sains masih rendah. Studi PISA tahun 2012 menunjukkan bahwa dimensi "scientific processes or skills, concepts and content, context or application" peserta didik di bidang sains berada pada urutan "ke-64 dari 65 negara" (OECD, 2013). Selain itu, studi TIMSS tahun 2011 menunjukkan bahwa dimensi "knowing, applying, dan reasoning" peserta didik menempati urutan "ke-40 dari 42 negara". Hasil studi ini menunjukkan pembelajaran IPA masih dalam level rendah dengan penekanan pembelajaran pada penguasaan konsep.

Hasil penelitian Asbell-Clarke \& Rowe (2007) menunjukkan pembelajaran IPA belum sesuai dengan standar yang semestinya. Saat ini Abad 21 merupakan era globalisasi ditandai oleh perkembangan IPA dan teknologi dalam berbagai bidang kehidupan masyarakat yang sangat pesat. 
Oleh karena itu, diperlukan cara pembelajaran yang dapat menyiapkan peserta didik untuk mencapai literasi IPA dan teknologi, mampu berpikir logis, kritis, kreatif serta dapat berargumentasi secara benar. Hal ini dapat dicapai dengan pembelajaran IPA berbasis inkuiri yang mengintegrasikan keterampilan untuk mendukung 21st century skills.

Keterampilan abad 21 dijelaskan oleh Lembaga P21 (2009: 6-7) meliputi: (1) life and career skills, (2) learning and innovation skills, (3) critical thinking and problem solving, (4) comunication and colaboration, dan (5) information media and technologylk skills. Keterampilan tersebut dirangkum dalam sebuah skema yang disebut dengan pelangi keterampilanpengetahuan $21^{\text {st }}$ century knowledge-skills rainbow (Trilling \& Fadel, 2009) yang dijelaskan pada Gambar 1.

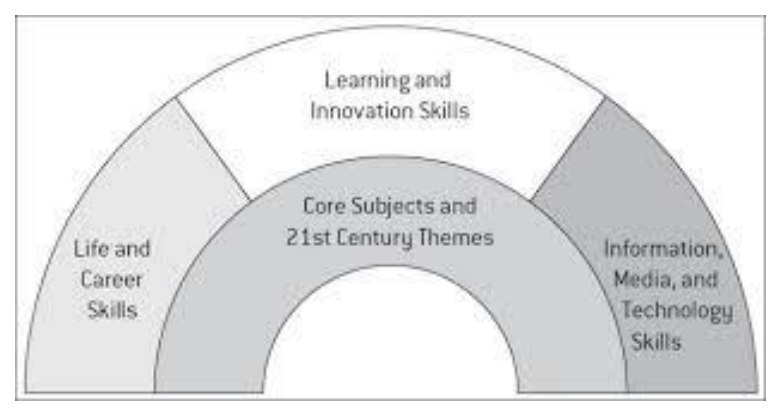

Gambar 1. Pelangi Keterampilan-

Pengetahuan Abad 21

Sumber: Trilling \& Fadel (2009)

Guru sebagai tenaga profesional yang memiliki tanggung jawab langsung terhadap kemajuan belajar peserta didiknya, diharapkan mampu mengembangkan proses pembelajaran sesuai dengan kompetensi mengajarnya secara mandiri (Yudhi, 2008). Hal ini sesuai dengan pendapat Cochran (1997) yang menyatakan guru harus mempunyai integrasi pengetahuan pedagogi dan pengetahuan konten ke dalam pedagogical content knowledge. Bentuk profesional guru didasarkan pada cara di mana guru berhubungan pengetahuan pedagogi mereka (apa yang mereka ketahui tentang mengajar) dan pengetahuan materi pelajaran (apa yang mereka ketahui tentang apa yang mereka ajarkan).

Proses pembelajaran di sekolah yang khususnya sasaran implementasi Kurikulum 2013 dengan scientific approach. Pendekatan saintifik yang digunakan dalam pembelajaran dikemas secara berurutan, menjadi (1) mengamati (observing), (2) menanya (questioning), (3) menalar (associating), (4) mencoba (experimenting) dan (5) membuat jejaring (networking). Pendekatan ilmiah (scientific approach) dalam pembelajaran meliputi mengamati, menanya, mencoba, mengolah, menyajikan, menyimpulkan, dan mencipta. Menurut Mc Komponen-komponen penting dalam mengajar menggunakan pendekatan scientifik diantaranya adalah guru harus menyajikan pembelajaran yang dapat meningkatkan rasa keingintahuan (foster a sense of wonder), meningkatkan keterampilan mengamati (encourage observation), melakukan analisis (push for analysis) dan berkomunikasi (require communication).

\section{METODE}

\section{Jenis Penelitian}

Jenis penelitian ini dilakukan dengan menggunakan jenis penelitian deskriptif analitik dengan pendekatan kualitatif, yaitu analisis isi (content analysis). Analisis isi adalah teknik penelitian untuk membuat inferensi-inferensi yang dapat ditiru (replicible), dan sahih data dengan memperhatikan koneksinya. Analisis isi pada awalnya digunakan dalam disiplin ilmu komunikasi yang dapat dimanfaatkan untuk penelitian yang bersifat normatif seperti pendapat sesorang atau sekelompok orang tentang hukum perkara. 


\section{Waktu dan Tempat Penelitian}

1. Penelitian ini dilaksanakan di sekolah dasar yang menjadi sasaran implementasi Kurikulum 2013 yang ada di lingkungan Dinas Pendidikan Kota Sukabumi.

2. Waktu Penelitian semester genap tahun ajaran 2017/2018 (Januari 2018 s/d Juli 2018)

\section{Target/Subjek Penelitian}

1. Populasi

Populasi dalam penelitian ini adalah peserta didik sekolah dasar yang ada di lingkungan Dinas Pendidikan Kota Sukabumi.

2. Sampel

Jumlah sampel penelitian ini adalah peserta didik sekolah dasar yang menjadi sasaran implementasi Kurikulum 2013 yang ada di lingkungan Dinas Pendidikan Kota Sukabumi. Teknik pengambilan sampel dengan menggunakan teknik sampling puposive, dengan cirinya ialah setiap unsur dari sampel dipilih berdasarkan kriteria tertentu.

\section{Prosedur}

Prosedur penelitian dengan metode deskriptik analitik ini ditempuh dengan melakukan studi kepustakaan (library research) atau dokumentasi, baik dari sumber data primer maupun sekunder yang membahas hal tersebut. Proses analisis meliputi langkah-langkah berikut:

1. Analisis pendahuluan. Analisis ini dilakukan terhadap hasil studi pendahuluan, atau data sekunder, yang akan digunakan untuk menentukan fokus penelitian. Analisis pendahuluan ini meliputi analisis lapangan pendahuluan dan analisis literatur. Analisis lapangan pendahuluan bertujuan untuk menghimpun data sekolah dasar yang telah menerapkan Kuirkulum 2013 dan menyebarkan lembar angket untuk mengetahui keterlaksanaan scientific approach dalam pembelajaran. Analisis literatur bertujuan untuk menguraikan aspek-aspek aktivitas peserta didik dalam pembelajaran dengan scientific approach.

2. Analisis lapangan. Analisis data pada penelitian kualitatif dilakukan saat pengumpulan data berlangsung dan setelah selesai pengumpulan data dalam periode tertentu. Analisis lapangan untuk mengamati keterlaksanaan pembelajaran scientific approach dan aktivitas peserta didik dalam mengikuti proses pembelajaran berbasis scientific approach Kurikulum 2013.

\section{Data, Instrumen, dan Teknik \\ Pengumpulan Data}

Teknik pengumpulan data yang digunakan dalam penelitian ini antara lain:

1. Wawancara

Wawancara pada penelitian ini digunakan sebagai teknik pengumpulan data ketika analisis pendahuluan dan analisis lapangan untuk mengungkap keterlaksanaan pembelajaran dengan scientific approach.

2. Observasi

Observasi ini digunakan pada saat analisis lapangan untuk mengamati keterlaksanaan pembelajaran scientific approach dan aktivitas peserta didik dalam mengikuti proses pembelajaran berbasis scientific approach Kurikulum 2013. Teknik ini dilengkapi dengan lembar observasi dilengkapi rubrik penilaiannya, sehingga memudahkan observer dalam melakukan pengamatan. 


\section{Teknik Analisis Data}

Analisis hasil wawancara dilakukan secara kualitatif dengan cara menyajikan kata-kata secara deskriptif. Sesuai dengan maknanya analisis kualitatif diartikan sebagai usaha analisis berdasarkan kata-kata yang disusun dalam bentuk teks yang diperluas, untuk menjelaskan beberapa pertanyaan yang telah dirumuskan.

Analisis aktivitas peserta didik dan keterlaksanaan pembelajaran scientific approach dilakukan dengan langkah analisis sebagai berikut.

1) Menghitung keterlaksanaan tahapan pembelajaran inkuiri dan aktivitas peserta didik.

$$
\mathrm{P}=\frac{\Sigma \mathrm{X}}{\mathrm{n}} \times 100 \%
$$

Keterangan:

$\mathrm{P}=$ Keterlaksanaan $(\%)$

$\sum \mathrm{X}=$ Jumlah tahapan yang terlaksana

$\mathrm{n} \quad=$ Jumlah seluruh tahapan pembelajaran

2) Mengkonversi nilai kuantitatif menjadi kualitatif sesuai Tabel 1.

Tabel 1

Konversi Persentase Menjadi Kategori

\begin{tabular}{lcc}
\hline No. & $\begin{array}{c}\text { Persentase } \\
(\boldsymbol{\%})\end{array}$ & Kategori \\
\hline 1. & $\geq 80$ & Sangat Baik \\
2. & $>60-80$ & Baik \\
3. & $>40-60$ & Cukup \\
4. & $>20-40$ & Kurang \\
5. & $\leq 20$ & Sangat Kurang \\
\hline
\end{tabular}

\section{HASIL DAN PEMBAHASAN}

Penelitian ini bertujuan untuk memetakan aktivitas peserta didik dalam pembelajaran berbasis scientific approach. Hasil penelitian diperoleh melalui wawancara dan observasi yang dilakukan pada Bulan Januari s.d. Mei di beberapa sekolah antara lain SDN Cikole, SDN
Cisaat, SDN Cimanggah 1, SDN Dewi Sartika CBM, dan SDN Cipanengah CBM dengan berbagai tingkatan kelas yang berbeda. Berdasarkan hasil penelitian terhadap aktivitas belajar peserta didik dalam proses pembelajaran dengan scientific approach Kurikulum 2013 dapat dipaparkan sebagai berikut.

Fokus pengamatan dalam penelitian ini yaitu aktivitas belajar peserta didik pada setiap langkah scientific approach. Berdasarkan hasil observasi dan analisis data maka dapat dipetakan aktivitas belajar peserta didik yang disajikan pada Gambar 2 berikut.

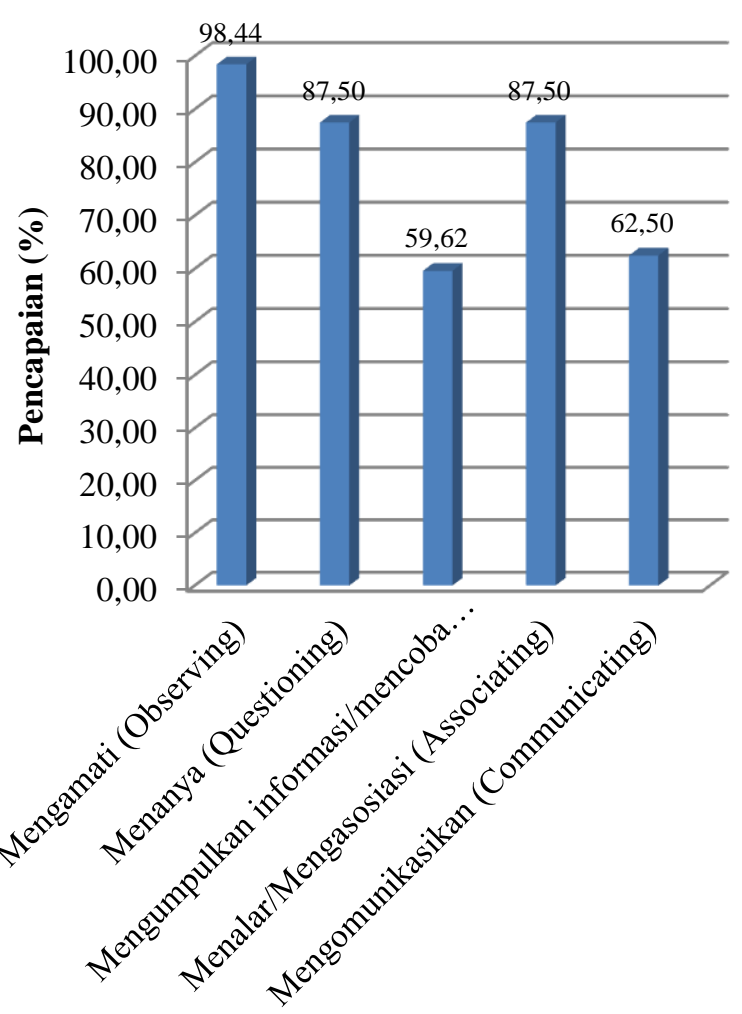

\section{Aspek observasi (Tahapan Scientific Approach)}

Gambar 2. Diagram Pencapaian Aktivitas Belajar Peserta didik

Fokus observasi pada penelitian ini yaitu pada pengalaman belajar scientific approach yang terdiri dari mengamati (observing), menanya (questioning), mengumpulkan informasi/eksperimen 
(experimenting), mengasosiasikan/ mengolah informasi (associating), dan mengkomunikasikan (communicating). Pada proses pembelajaran ini yaitu mempunyai karakteristik tematik integratif. Webb \& Pearson (2012) menjelaskan bahwa kegiatan awal dalam pembelajaran tematik yaitu guru menganalisis tema yang akan pilih. Dengan demikian Guru dituntut untuk menyediakan kegiatan yang relevan dan konteks yang sangat bermakna bagi peserta didik.

\section{Mengamati (observing)}

Pada aspek mengamati, aktivtas belajar peserta didik yang diobservasi dalam mengikuti berbagai kegiatan meliputi pembiasaan untuk membaca, menemukan fokus pengamatan, ide pokok, pesan, makna dari objek yang diamatinya (fenomena alam, teks tertulis, tayangan video, dll.), menemukan kekeliruan-kekeliruan atau masalah pada objek pengamatan, menceritakan kembali hasil pengamatannya, bertanya dengan sudut pandangnya terhadap objek yang sedang diamati, menerima perbedaan sudut pandang terhadap objek pengamatan, merespon positif sudut pandang peserta didik lainnya yang berbeda terhadap objek pengamatan, dan pemberian pertanyaan penggiring untuk mengarahkan peserta didik pada saat mengamati. Berdasarkan hasil obesrvasi dan analisis data maka diperoleh informasi aktivitas belajar peserta didik pada tahap mengamati seperti yang disajikan pada Gambar 3.

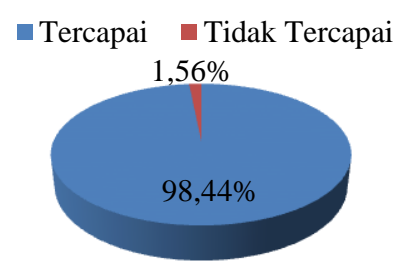

Gambar 3. Diagram Pencapaian Aktivitas Peserta Didik pada Tahap Mengamati
Berdasarkan indikator aktivitas mengamati tersebut, yang menjadi fokus observasi pada kegiatan ini adalah pengamatan langsung pada objek yang akan dipelajari oleh peserta didik, sehingga mendapatkan fakta yang objektif untuk dianalisis sesuai dengan tingkat perkembangan peserta didik. (Goldston \& Downey, 2013) menjelaskan bahwa kegiatan mengamati dapat mendorong peserta didik menggunakan semua indera (penglihatan, pendengaran, sentuhan, penciuman, dan rasa saat yang tepat) untuk memberikan informasi yang maksimal ketika mengamati fenomena alam.

Pada pembiasaan peserta didik untuk membaca, sebelum peserta didik menerima materi dari guru, peserta didik menemukan sendiri informasi tersebut melalui membaca. Peserta didik diberikan kesempatan untuk membaca dan menemukan sendiri materi yang akan dibelajarkan. Proses pembelajaran diarahkan lebih melibatkan peserta didik sebagai subyek (Dewi, 2018) dan lebih termotivasi sehingga akan memudahkkan pendidik dalam menyampaikan materi pelajaran (Sari \& Sugiyarto, 2015). Selama kegiatan pembelajaran berlangsung peserta didik mengamati objek gambar yang berkaitan dengan materi yang akan disampaikan, lalu meminta peserta didik untuk mencari informasi objek gambar melalui kegiatan membaca buku pegangan yang mereka miliki. Kegiatan tersebut tentu untuk menumbuhkan kebiasaan budaya membaca dalam diri peserta didik. Selain itu, kegiatan mengamati untuk menstimulus peserta didik untuk berpikir dan mengkonstruk kembali pemahaman mereka mengenai materi yang dibelajarkan. Pendapat tersebut sejalan dalam perbahasan jurnal creative Thinking 
yang membahas bahwa mengobservasi dapat menstimulus peserta didik untuk berpikir dan mengkonstruk kembali pemahan tertakait materi pembelajaran (Anwar et al., 2012).

Pada kegiatan guru dalam memfasilitasi peserta didik untuk menemukan fokus pengamatan, ide pokok, pesan, makna dari objek yang diamatinya, ini telah dicapai oleh semua sekolah. Berdasarkan hasil pengamatan, peserta didik difasilitasi dengan menggunakan media pembelajaran. Hal ini dilakukan guru agar memperjelas konsep dan memudahkan dalam menyampaikan materi yang diajarkan pada peserta didik, serta membantu peserta didik untuk memahami materi dengan memperhatikan objek yang di tampilkan guru melalui media.

Kegiatan guru dalam memfasilitasi peserta didik menemukan kekeliruankekeliruan atau masalah pada objek pengamatan, indikator ini telah dicapai oleh semua sekolah. Berdasarkan hasil pengamatan, peserta didik mengamati beberapa objek/gambar yang berbeda. Hal ini misalnya pada pembelajaran kelas IV SDN Cipanengah peserta didik diminta mengamati gambar metamorfosis yang dipersiapkan oleh guru, lalu melakukan perbandingan antara gambar hewan yang satu dengan yang lainnya. Peserta didik diberikan fasilitas untuk menemukan permasalahan yang berkaitan dengan objek yang sedang peserta didik amati.

Pada kegiatan pemberian kesempatan pada peserta didik untuk menceritakan kembali hasil pengamatannya, indikator ini tidak dicapai oleh satu sekolah dikarenakan waktu yang dibutuhkan tidak mencukupi, sehingga guru melanjutkan ke kegiatan pembelajaran yang selanjutnya. Namun demikian, di sekolah yang lain setelah peserta didik mengamati beberapa objek gambar yang ditunjukkan oleh guru, peserta didik diberikan kesempatan untuk menceritakan dari hasil yang diamatinya. Seperti contoh peserta didik menceritakan bagaimana tugas seorang ilmuwan, arsitek, dokter, guru dan astronot. Selain itu, peserta didik juga mengamati berbagai hewan yang mengalami metamorfosis. Peserta didik diberikan kesempatan untuk menceritakan hasil pengamatannya secra bergiliran pada masing-masing kelompok.

Kegiatan guru dalam menstimulus peserta didik untuk berani bertanya dengan sudut pandngnya terhadap objek yang sedang diamati, indikator ini telah dicapai oleh semua sekolah. Berdasarkan hasil pengamatan, peserta didik melakukan kegiatan belajar secara aktif baik fisik maupun mental. Guru terampil untuk mengaktifkan peserta didiknya di dalam pembelajaran dengan memiliki kemampuan berempati, menjadi pendengar yang baik, dan bisa menjadi fasilitator bagi peserta didik dalam memecahkan masalah mereka oleh mereka sendiri, sehingga peserta didik dapat aktif bertanya menurut sudut pandangnya. Bertanya dalam pembelajaran dipandang sebagai kegiatan yang mampu mendorong, membimbing dan menilai kemampuan berfikir peserta didik. Bagi peserta didik bertanya merupakan bagian penting dalam proses belajar mengajar karena peserta didik dapat menggali informasi, mengkonfirmasikan apa yang sudah diketahui, dan mengarahkan perhatian pada aspek yang belum diketahuinya.

Pada kegiatan guru dalam mengkondisikan peserta didik untuk menerima perbedaan sudut pandang terhadap objek pengamatan, indikator ini dicapai oleh semua sekolah. Berdasarkan hasil pengamatan, terjadi kegiatan tanya jawab antara guru dan peserta didik serta peserta didik dengan peserta didik lainnya. 


\section{Analisis Aktivitas Peserta Didik dalam Pembelajaran Berbasis Scientific Approach di Sekolah Dasar sebagai Implementasi 21st Century Skills}

Peserta didik dibimbing untuk menghargai setiap pendapat yang dikemukakan oleh temannya mengenai pengamatan objek dan materi yang dipelajari, dengan cara memperhatikan dan mendengarkan temannya yang sedang berbicara.

Pada kegiatan guru dalam mengkondisikan peserta didik untuk selalu merespon positif sudut pandang peserta didik lainnya yang berbeda terhadap objek pengamatan, indikator ini dicapai oleh semua sekolah. Berdasarkan dari hasil pengamatan, peserta didik dapat merespon positif sudut pandang terhadap objek pengamatan dari peserta didik satu dengan yang lainnya dengan menghargai dan mendengarkan dengan seksama. Selain itu, peserta didik juga melakukan tepuk tangan bagi peserta didik yang berani mengemukakan pendapatnya.

Pada kegiatan guru dalam memberikan pertanyaan-pertanyaan penggiring/pengarah untuk mengarahkan peserta didik pada saat mengamati, indikator ini dicapai oleh semua sekolah. Berdasarkan hasil pengamatan, peserta didik diarahkan pada pikiran yang linier dengan tujuan yang diinginkan dengan kata lain, peserta didik tidak sembarangan memberikan jawaban atas pertanyaan yang diberikan oleh guru untuk mencapai tujuan pembelajaran. Pertanyaan yang diajukan juga mengarahkan peserta didik pada pemahaman yang tepat tentang materi yang sedang dibahas. Hal ini agar tidak akan memberikan peluang pada peserta didik untuk memberikan jawaban yang jauh dari sasaran ketercapaian tujuan pembelajaran.

\section{Menanya (questioning)}

Pada aspek menanya, aktivtas belajar peserta didik yang diobservasi dalam mengikuti berbagai kegiatan meliputi bertanya sesuai dengan cakupan materi pembelajaran dan fokus pengamatan melalui pertanyaan-pertanyaan pengiring/pengarah, bertanya menggunakan pertanyaan prosedural atau hipotesis, menjawab pertanyaannya sendiri dan/atau pertanyaan peserta didik lain, mengajukan pertanyaan yang berbeda dengan peserta didik lain, mengajukan pertanyaan yang beragam mulai dari pertanyaan faktual, konseptual, procedural, dan hipotetis, dan bertanya secara lisan dan/atau tulisan dengan Bahasa Indonesia yang baik, benar, dan mudah dipahami. Berdasarkan hasil obesrvasi dan analisis data maka diperoleh informasi aktivitas belajar peserta didik pada tahap menanya seperti yang disajikan pada Gambar 4.

$$
\text { - Tercapai } \quad \text { Tidak Tercapai }
$$

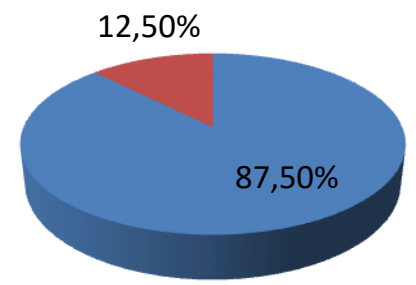

Gambar 4. Diagram Pencapaian Aktivitas

Peserta Didik pada Tahap Menanya

Pada kegiatan dalam rangka memfasilitasi peserta didik untuk bertanya sesuai dengan cakupan materi pembelajaran dan fokus pengamatan melalui pertanyaanpertanyaan pengiring/pengarah, indikator ini dicapai oleh semua sekolah. Berdasarkan hasil pengamatan, peserta didik diberikan kesempatan untuk bertanya secara langsung tentang cakupan materi yang telah dibaca pada buku peserta didik atau sesuai fakta yang telah ditampilkan pada gambar. Hal ini dapat dibuktikan ketika guru menayangkan objek gambar mengenai cita-cita, lalu peserta didik diberi kesempatan untuk 
bertanya yang berkaitan dengan objek tersebut.

Pada kegiatan dalam rangka membiasakan peserta didik untuk bertanya menggunakan pertanyaan prosedural atau hipotesis, indikator ini tidak dicapai oleh 3 sekolah. Berdasarkan hasil pengamatan, tidak terlihat peserta didik bertanya menggunakan pertanyaan prosedural atau hipotesis karena peserta didik bertanya sesuai dengan apa yang dia lihat atau bersifat faktual. Hal ini terlihat saat peserta didik mengajukan pertanyaan yang berkaitan dengan fakta yang peserta didik lihat.

Pada kegiatan dalam rangka memberikan kesempatan kepada peserta didik untuk menjawab pertanyaannya sendiri dan/atau pertanyaan peserta didik lain, indikator ini dicapai oleh semua sekolah. Berdasarkan hasil pengamatan, peserta didik diberikan kesempatan untuk menjawab pertanyaan dari guru atau pertanyaan dari peserta didik lain, agar peserta didik dapat melatih kemampuan berfikirnya. Setelah itu guru memberikan konfirmasi terhadap jawaban peserta didik, hal ini terlihat saat peserta didik menjawab pertanyaan tentang tugas-tugas profesi yang ditampilkan pada gambar.

$\begin{array}{cccr}\text { Pada } & \text { kegiatan dalam } & \text { rangka } \\ \text { menstimulus } & \text { peserta } & \text { didik } & \text { untuk } \\ \text { mengajukan } & \text { pertanyaan } & \text { yang } & \text { berbeda }\end{array}$
dengan peserta didik lain, indikator ini tidak dicapai oleh satu sekolah. Hal ini dikarenakan peserta didik belum terbiasa dan masih malu untuk mengajukan pertanyaan. Namun demikian, mayoritas sekolah yang lain peserta didik diberikan kesempatan untuk bertanya yang berbeda dengan materi yang sama agar peserta didik lain juga dapat mempunyai kesempatan untuk aktif dalam proses pembelajaran. Hal ini terlihat saat peserta didik diberikan kesempatan untuk bertanya oleh guru pada masing-masing kelompok dengan pertanyaan yang berbeda.

Pada kegiatan dalam rangka memberikan kesempatan kepada peserta didik untuk mengajukan pertanyaan yang beragam mulai dari pertanyaan faktual, konseptual, prosedural, dan hipotetis, indikator ini tidak dicapai oleh 2 sekolah. Hal ini dikarenakan peserta didik tidak aktif mengajukan pertanyaan-pertanyaan yang beragam, baik pertanyaan prosedural atau pun hipotesis. Namun demikian mayoritas sekolah yang lain peserta didik sudah mulai memberikan pertanyaan yang bersifat faktual sesuai dengan fakta yang ditampilkan oleh guru, misalnya sesuai dengan gambar yang diamati.

Pada kegiatan dalam rangka membiasakan peserta didik untuk bertanya secara lisan dan/atau tulisan dengan Bahasa Indonesia yang baik, benar, dan mudah dipahami, indikator ini tercapai oleh semua sekolah. Berdasarkan hasil pengamatan peserta didik mengajukan pertanyaan secara lisan saja dengan menggunakan Bahasa Indonesia yang baik, benar dan mudah di pahami berdasarkan bimbingan guru. Hal ini terlihat ketika peserta didik mengajukan pertanyaan lalu guru memberikan masukan atau arahan saat mengajukan pertanyaan dengan suara yang lantang agar dapat dipahami oleh peserta didik lain.

\section{Mengeksperimen (experimenting)}

Pada aspek mengumpulkan informasi/eksperimen, aktivitas belajar peserta didik yang diobservasi dalam mengikuti berbagai kegiatan meliputi memilih informasi/data/bukti yang penting untuk dikumpulkan, memilih beragam teknik pengumpulan informasi yang dapat dilakukan sesuai dengan kebutuhan, memilih alat ukur yang sesuai ketika 


\section{Analisis Aktivitas Peserta Didik dalam Pembelajaran Berbasis Scientific Approach di Sekolah Dasar sebagai Implementasi 21st Century Skills}

melakukan pengukuran, menentukan apa yang akan diukur pada saat mengukur menggunakan alat, menggunakan beragam teknik dan instrumen pengumpul data/informasi, menggunakan beragam cara pada saat melakukan percobaan, membuat karya yang unik dan berbeda dengan peserta didik lain, mengumpulkan bukti dalam beragam konteks, menggunakan model atau simulasi untuk menggali sistem atau masalah yang kompleks, bekerjasama dengan teman sekelompoknya dalam mengumpulkan informasi, membantu teman yang mengalami masalah pada saat mengumpulkan informasi, mengerjakan tugas sesuai dengan tanggung jawabnya pada kelompok, dan menerima kontribusi peserta didik lain dalam kelompok pada saat mengumpulkan informasi. Berdasarkan hasil obesrvasi dan analisis data maka diperoleh informasi aktivitas belajar peserta didik pada tahap mengumpulkan informasi/ eksperimen seperti yang disajikan pada Gambar 5.

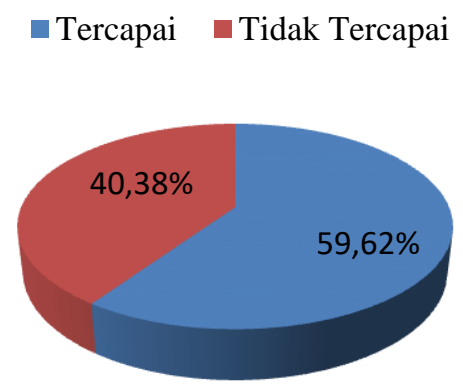

Gambar 5. Diagram Pencapaian Aktivitas Peserta Didik pada Tahap Mengeksperimen

Berdasarkan hasil pengamatan di beberapa sekolah observasi diperoleh informasi bahwa dalam kegiatan pembelajaran tersebut indikator belajar peserta didik dalam mengumpulkan informasi/mencoba belum sepenuhnya tercapai karena ada beberapa komponen yang tidak muncul saat proses pembelajaran. Dari 13 indikator, terdapat 5 indikator yang hanya dicapai $\leq 50 \%$ dari jumlah sekolah yang diobservasi. Ketidak tercapaian indikator pada saat proses pembelajaran seperti tidak ada kegiatan pembelajaran yang melibatkan peserta didik untuk memilih alat ukur yang sesuai ketika peserta didik melakukan pengukuran. Oleh karena itu, peserta didik tidak dibimbing untuk menentukan apa yang akan diukur pada saat mengukur menggunakan alat dan peserta didik tidak di fasilitasi beragam teknik dan instrumen pengumpul data/informasi. Pada saat proses pembelajaran berlangsung, peserta didik tidak dikondisikan untuk menggunakan beragam cara pada saat melakukan percobaan, karena pada saat tersebut tidak terdapat pembelajaran yang harus menuntut peserta didik untuk menghasilkan karya. Serta tidak ada stimulus kepada peserta didik untuk menggunakan model atau stimulasi untuk menggali sistem atau masalah yang kompleks. Hal ini sesuai dengan penelitian Novianto \& Mustadi (2015), banyak guru yang belum mengimplementasikan sistem pembelajaran tematik yang lebih menekankan pada keterlibatan peserta didik dalam proses belajar secara aktif. Padahal semakin aktif anak terlibat dalam kegiatan belajar, semakin besar perolehan dan pemahamannya akan pengetahuan yang dipelajari (Niron et al., 2013).

Adapun komponen yang sudah tercapai yaitu pada saat pembelajaran berlangsung peserta didik diminta untuk mencari informasi bersama teman, disini peserta didik diberikan kesempatan untuk memilih informasi/data/bukti yang penting untuk dikumpulkan serta memberikan kesempatan kepada peserta didik untuk 
memilih beragam teknik pengumpulan informasi yang dapat dilakukan sesuai dengan kebutuhan. Sebelum proses pembelajaran, guru sudah mengatur tempat duduk peserta didik secara berkelompok agar peserta didik selalu bekerjasama dengan teman sekelompoknya dalam mengumpulkan informasi sehingga membiasakan peserta didik untuk membantu teman yang mengalami masalah pada saat mengumpulkan informasi, mengerjakan tugas sesuai dengan tanggung jawabnya pada kelompok dan menerima konstribusi peserta didik lain dalam kelompok pada saat mengumpulkan informasi.

Mengembangkan keterampilan proses, membantu peserta didik belajar menggunakan metode ilmiah dalam memecahkan masalah, menentukan sebab akibat serta menguatkan informasi dapat dilakukan dengan proses pembelajaran minilab. Budiman (2017) menjelaskan bahwa pembelajaran tersebut dapat memberikan kesempatan pada peserta didik untuk terlibat (secara kognitif, afektif, dan psikomotor) dengan tahap-tahap inkuiri dalam proses penyelidikan dan penemuan prinsip atau konsep. Hal ini sesuai yang dinyatakan oleh Ambarsari \& Slamet (2013) tentang pembelajaran berbasis inkuiri yaitu efektif untuk membuat variasi suasana pola pembelajaran di kelas.

\section{Mengasosiasikan/mengolah informasi (associating)}

Pada aspek menalar/mengasosiasi, aktivtas belajar peserta didik yang diobservasi dalam mengikuti berbagai kegiatan meliputi memilih informasi yang penting dan dibutuhkan, menemukan keterkaitan antara informasi yang satu dengan informasi lainnya, menemukan pola dari keterkaitan informasi, menarik simpulan dari informasi/data yang terkumpul, menggunakan beragam teknik pengolahan data, menyajikan informasi/data dalam bentuk tabel atau diagram untuk memudahkan dalam membaca informasi. Berdasarkan hasil obesrvasi dan analisis data maka diperoleh informasi aktivitas belajar peserta didik pada tahap menalar/mengasosiasi seperti yang disajikan pada Gambar 6.

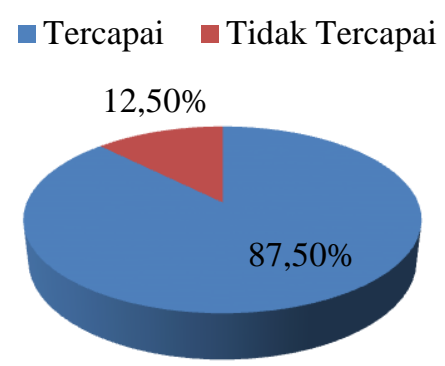

Gambar 6. Diagram Pencapaian Aktivitas
Peserta didik Pada Tahap
Menalar/Mengasosiasi

Dari hasil observasi diperoleh informasi bahwa pada indikator menalar/mengasosiasi belum sepenuhnya tercapai karena ada beberapa komponen yang kurang sesuai saat pembelajaran berlangsung, sehingga ketercapaian indikator ini sebesar $87,5 \%$. Semua indikator tercapai oleh semua sekolah, kecuali indikator memberikan kesempatan kepada peserta didik untuk memilih informasi yang penting dan dibutuhkan, memfasilitasi peserta didik untuk menggunakan beragam teknik pengolahan data, dan memfasilitasi peserta didik untuk menyajikan informasi/data dalam bentuk tabel atau diagram untuk memudahkan dalam membaca informasi.

Pada pembelajaran tersebut peserta didik diberikan kesempatan untuk memilih informasi yang penting dan dibutuhkan, misalnya dalam lembar kerja peserta didik tentang percakapan antara Udin, Siti dan Beni. Pada kegiatan tersebut peserta didik 
mencari dan memilih informasi untuk menemukan jawaban yang tepat dan benar serta menemukan keterkaitan antara informasi yang satu dengan informasi lainnya untuk menemukan pola dari keterkaitan informasi. Misalnya pada saat peserta didik mendengarkan percakapan tersebut, peserta didik mencari informasi untuk menemukan keterkaitan informasi dalam percakapan untuk menemukan jawaban dari pola yang dihasilkan. Setelah itu peserta didik diberikan kesempatan untuk menarik kesimpulan dari informasi tentang percakapan antara Udin, Siti, dan Beni. Makna tahap mengasosiasi ini sesuai dengan esensi pembelajaran tematik integratif yaitu memberikan kesempatan kepada peserta didik untuk menghubungkan pengalaman dan pengetahuan yang dimiliki, sehingga peserta didik lebih mudah menyelesaikan masalah dan memenuhi kebutuhan mereka akan pengetahuan (Huber \& Hutchings, 2008).

Selain itu, kegiatan peserta didik saat diobservasi juga diberikan tabel untuk memudahkan dalam membaca informasi dan menyajikan data dan informasi. Seperti pada tabel rumpang yang tidak lengkap, peserta didik difasilitasi tabel untuk mengamati bilangan-bilangan yang ada untuk selanjutnya peserta didik menuliskan bilangan hingga lengkap. Pada pembahasan menganai aturan bermain bersama teman, peserta didik juga difasilitasi tabel untuk memudahkan dalam mendapatkan informasi yang didapat dari hasil wawancara dengan peserta didik lain. Akan tetapi dalam kegiatan tersebut, peserta didik tidak difasilitasi untuk menggunakan teknik lain selain wawancara untuk mendapat informasi tersebut.

\section{Mengkomunikasikan (communicating)}

Pada aspek mengkomunikasikan, aktivtas belajar peserta didik yang diobservasi dalam mengikuti berbagai kegiatan meliputi menyajikan laporan dalam bentuk bagan, tabel, diagram, dan grafik sehingga mudah dipahami peserta didik lain, menyajikan laporan secara tertulis dengan Bahasa Indonesia yang baik dan benar, mempresentasikan proses dan hasil pengumpulan dan pengolahan informasi dengan Bahasa Indonesia yang baik dan benar, mempresentasikan keunggulan karya yang dibuatnya, memajang hasil karya dengan rapi dan mudah untuk dijangkau peserta didik lain, dan memeragakan suatu prosedur tertentu dengan luwes dan terampil. Berdasarkan hasil obesrvasi dan analisis data maka diperoleh informasi aktivitas belajar peserta didik pada tahap mengkomunikasikan seperti yang disajikan pada Gambar 7.

$$
\text { - Tercapai } \quad \text { Tidak Tercapai }
$$

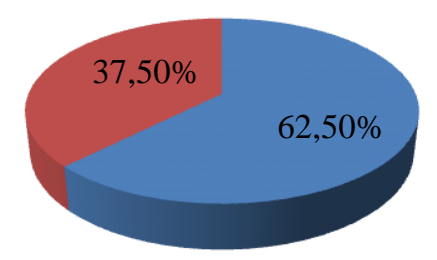

Gambar 7. Diagram Pencapaian Aktivitas
Peserta didik Pada Tahap
Mengkomunikasikan

Dari hasil observasi diperoleh informasi bahwa pada indikator bahwa pada indikator mengkomunikasikan terdapat semua komponen belum sepenuhnya tercapai. Dari keenam indikator, ada beberapa sekolah yang tidak mampu mencapai. Tahap ini kegiatan pembelajaran yang dilakukan peserta didik difasilitasi 
tabel untuk memudahkan dalam menemukan informasi, tabel tersebut memudahkan peserta didik dalam menyajikan laporan agar dapat dipahami oleh peserta didik lain. Dalam menyajikan laporan tersebut peserta didik dibiasakan untuk menggunakan Bahasa Indonesia yang baik dan benar, hal ini untuk menumbuhkan kebiasaan berbahasa yang baik dan benar pada peserta didik.

Akan tetapi dalam mempresentasikan laporannya, peserta didik belum difasilitasi untuk mempresentasikan proses dan hasil pengumpulan dan pengolahan informasi secara menyeluruh. Karena peserta didik hanya difasilitasi untuk mempresentasikan hasil wawancara mengenai aturan bemain bersama teman, hal tersebut disebabkan oleh keterbatasan waktu yang tidak mencukupi. Selain itu, karena pada pembelajaran yang dilakukan tidak terdapat kegiatan yang mengharuskan peserta didik membuat suatu karya, maka peserta didik pun tidak mempresentasikan hasil karya yang dibuat. Hal tersebut berdampak pada komponen lainnya, dimana peserta didik juga tidak memajang hasil karya atau pun memeragakan suatu prosedur tertentu.

Pembahasan yang telah diuraikan tersebut merupakan aktivitas belajar peserta didik yang diobservasi dalam kegiatan scientific approach. (Nasser, 2014) menyatakan bahwa "The approach elicited the knowledge of stakeholders and experts in the field" artinya pendekatan mampu menimbulkan pengetahuan. Pendekatan ilmiah dalam Kurikulum 2013 ini memiliki sasaran pembelajaran yang mencakup pengembangan ranah sikap, pengetahuan, dan keterampilan.

\section{SIMPULAN DAN SARAN Simpulan}

Hasil analisis aktivitas peserta didik dalam pembelajaran dengan scientific approach sebagai implementasi 21 st century skills diperoleh informasi bahwa aktivitas belajar peserta didik dalam mengamati (observing) mencapai 98,44\%, menanya (questioning) mencapai 87,50\%, mengumpulkan informasi leksperimen (experimenting) mencapai 59,62\%, mengasosiasikan/ mengolah informasi (associating) mencapai 87,50\%, dan mengkomunikasikan (communicating) mencapai $62,50 \%$. Secara rata-rata keseluruhan aktivitas peserta didik dalam mengikuti proses pembelajaran di sekolah dasar dengan scientific approach tercapai $76,60 \%$ dengan kategori Baik.

\section{Saran}

Rekomendasi berdasarkan hasil penelitian ini supaya scientific approach dapat diimplementasikan dalam pembelajaran yang mengacu kepada Kurikulum 2013, maka tenaga pendidik diharapkan dapat benar-benar menguasai Kurikulum 2013 antara lain: 1) mempersiapkan alat dan sumber belajar yang tepat untuk diterapkan di kelas rendah maupun tinggi, agar proses pembelajaran menjadi lebih efektif, agar dapat terlaksananya proses pembelajaran dengan scientific approach yang lebih terarah, bermakna dan lebih optimal; 2) supaya proses pembelajaran tidak terpaku pada buku peserta didik maka guru perlu menggunakan media pembelajaran yang lebih beragam dan menarik, sehingga pembelajaran dapat lebih menyenangkan; 3) Pembiasaan dan penanaman 21 st century skills dalam scientific approach tetap dipertahankan pelaksanaannya dan selalu memperbaiki kelemahan-kelemahan yang ada serta terbuka dengan adanya kritik dan 
saran dari semua pihak dalam mengupayakan telaksananya pembelajaran yang lebih bermutu.

\section{DAFTAR PUSTAKA}

Ambarsari, W, Slamet, S. \& M. (2013). Penerapan pembelajaran inkuiri terbimbing terhadap keterampilan proses sains dasar pada pelajaran biologi peserta didik kelas VIII SMP Negeri 7. Pendidikan Biologi, 5(1), 8195.

Anwar, M.N.; Shamim-ur-Rasool, S.; Haq, R. (2012). A comparison of creative thinking abilities of high and low achievers secondary school. International Interdisciplinary Journal of Education, 1(1), 23-28.

Asbell-Clarke, J., \& Rowe, E. (2007). Learning science online: A descriptive study of online science courses for teachers. ... Asynchronous Learning ..., 11(3), 95-121. Retrieved from http://www.life.umd.edu/grad/MLfsc/J ALN.V11,3.pdf

Budiman, I. (2017). Model pembelajaran latihan inkuiri untuk meningkatkan penguasaan konsep energi rumah tangga dan keterampilan berpikir kreatif siswa SMP. Jurnal Pendidikan Pascasarjana Magister PAI, 1(1), 4046.

Cochran, K. F. (1997). Pedagogical content knowledge: Teachers' integration of subject matter, pedagogy, students, and learning environments [online]. Research Matters-to The Science Teacher, No. 9702, Jan. 14.

Dewi, N. D. L. (2018). Penerapan pembelajaran IPA terintegrasi untuk memetakan nilai iman (budi pekerti) peserta didik sekolah dasar. JIPVA (Jurnal Pendidikan IPA Veteran), 2(1), 36-47.
Goldston, Marion J.; Downey, L. M. (2013). Your Science Classroom: Becoming an Elementary School Science Teacher. Los Angeles: SAGE Publications, Inc.

Huber, M.T.; Hutchings, P. (2008). Integrative learning: mapping the terrain. International Journal for The Scholarships of Teaching \& Learning, 2, 14-20.

Liliasari. (2012). Pengembangan alat ukur berpikir kritis pada konsep termokimia untuk peserta didik SMA peringkat atas dan menengah. Jurnal Pendidikan Indonesia, 1, 21-26.

Nasser, R. (2014). A methodological and scientific approach to developing a research ageda in education. Journal of Applied Sciences, 14(19), 2359-2366.

Niron, M.D.; Budiningsih, C.A., Pujiriyanto (2013). Rujukan integratif dalam pelaksanaan pendidikan karakter di Sekolah Dasar. Jurnal Kependidikan, 43(1), 19-31.

Novianto, Anwar; Mustadi, A. (2015). Analisis buku teks muatan tematik integratif, scientific approach, dan authentic assessment sekolah dasar. Jurnal Kependidikan, 45(1), 1-15.

OECD. 2013. PISA 2012 Results in Focus What 15-year-olds know and what they can do with what they know. http://www.oecd.org/pisa/keyfindings/p isa-2012-results-overview.pdf diakses pada 27 Januari 2014

P21. 2009. P21 Framework Definitions. Diambil pada september 2013, dari http://www.p21.org/storage/documents/ P21_Framework_Definitions.pdf.

Sari, D. S., \& Sugiyarto, K. H. (2015). Pengembangan multimedia berbasis masalah untuk meningkatkan motivasi belajar dan kemampuan berpikir kritis siswa. Jurnal Inovasi Pendidikan IPA, 1(2), 153-166. Retrieved from http://journal.uny.ac.id/index.php/jipi\% 
5CnPENGEMBANGAN

Trilling, B.; Fadel, C. (2009). 21st Century skills: learning for life in our times. John Wiley \& Sons, Inc.

Webb, P.I.; Pearson, P. J. (2012). Creative unit and lesson planning through a thematic/integrated approach to teaching games for understanding (TGfU). New Zealand Physical Educator, 45(3), 17-22.

Yudhi, M. (2008). Media pembelajaran sebuah pendekatan baru. Jakarta: Gaung Persada Press.

\section{PROFIL SINGKAT}

\section{Din Azwar Uswatun}

Penulis lahir di Klaten tanggal 3 Oktober 1990. Riwayat pendidikan penulis jenjang Sarjana diselesaikan pada Program Studi Pendidikan IPA FMIPA Universitas Negeri Yogyakarta tahun 2013. Pendidikan jenjang Magister Pendidikan Sains konsentrasi IPA diselesaikan di PPs Universitas Negeri
Yogyakarta tahun 2015. Saat ini penulis bekerja sebagai Dosen Pendidikan Guru Sekolah Dasar FKIP Universitas Muhammadiyah Sukabumi dan aktif dalam kegiatan penelitian dan pengabdian kepada masyarakat. Penulis dapat dihubungi via email di: dinazwar@ummi.ac.id.

\section{Rohmat Widiyanto}

Penulis lahir di Wonoharjo tanggal 13 September 1989. Riwayat pendidikan penulis jenjang Sarjana diselesaikan pada Program Studi Pendidikan Guru Sekolah Dasar (PGSD) Universitas Bengkulu tahun 2012. Pendidikan jenjang Magister Pendidikan Dasar diselesaikan di Universitas Pendidikan Indonesia tahun 2014. Saat ini penulis bekerja sebagai Dosen PGMI Universitas Islam Negeri Syarif Hidayatullah Jakarta. Penulis dapat dihubungi di: widiyantorohmat@yahoo.com 